\title{
RESEARCH PROBLEMS IN S-2 THESES
}

\author{
Rahmadi Nirwanto \\ STAIN Palangkaraya \\ rnirwanto@yahoo.com
}

\begin{abstract}
The study is intended to identify, classify, evaluate, describe, and explain the quality and the patterns of research problems in the S-2 theses of the English Education Program at Islamic University of Malang. Qualitative approach and evaluation designs were used. The data of the study were 135 of S-2 theses of the English Education Program at Islamic University of Malang from 2003-2008. The study reveals that the majority of the research problems, as written in the theses, indicate clarity, researchability, variables being involved, areas, designs, non-factual data or information, and significance.
\end{abstract}

Key words: research, problems, statements, writing, theses

In research, the term of "research problem," "research question," or "research statement" which can be used interchangeably are commonly familiar. A research problem, preferred henceforward, is also the most important aspect (Ary et. al, 2006:42). Kumar (1996:31) uses the foundation of a building as an analogy to describe the important role of problems in research. He pictures that type and design of a building depend upon the foundation. If the foundation is well designed and strong, we may expect that the building will be strong, too. On the other hand, if the foundation is weak, the whole building will collapse. In the same sense, the foundation of research is a research problem. If a research problem is well-formulated, we may expect that the other research activities can be continued successfully. On the other hand, if a research problem is formulated unclearly, the whole process will be spoiled. Leedy (1980:50) points out that a research problem is paramount important to success of research effort. McMillan and Schumacher (1993:72) maintain that research problem communicate to others the focus and the importance of the problems, the educational context and the scope, and the framework for reporting the result.
Lacking of knowledge and understanding of the nature of research problems can be source of difficulties. As a consequence, researchers may formulate the problems haphazardly, which in turn, pitfalls or shortcomings in several methodological aspects such as in research designs, data collection and analysis, and conclusions drawing. Ideally, researchers, in this case, graduate students should not have difficulty in determination of research problems because they are assumed as educated people who have experiences in the world of professional practices. However, in reality, Gay (1987:31) found that some graduate students spend many anxiety ridden-day and sleepless night worrying about where are they going to find the problems they need for their thesis. Moreover, Kerlinger (1981:16) describes that it may even take years of exploration, thought, and research before what questions can be clearly said. Even, Latief (2004:32) reports that the graduate students of the English education program at State University of Malang are confronted with a situation which forces them to repeat all research activities to suit the research problems or change the research problems to adjust with the research results. Changing the research problems may 
be considered to be the easiest way but that is not recommended (Latief, 2004:32). Considering that the research problem is the most important part of research, the study on the research problems as written in the S-2 theses of the English Education Program at Islamic University of Malang from 2003-2008 is badly needed.

How well or poorly a research problem is formulated depends on the fulfillment of the certain criteria. A good research problem should meet the criteria as follow. First, research problems should be clear (Tuckman, 1999:28; Mc Millan, 1992:34; Fraenkel and Wallen, 2006:24). This implies that 1) words, phrases and sentences in research problems should not cause multi interpretations and 2) words, phrases and sentences should be free from ambiguity. Most people would agree as to what the key words in the question mean. Fraenkel and Wallen (2006:24) display examples of research questions that are not clear, they are "Is a humanistically oriented classroom effective?" and "How do teachers feel about special classes for the educationally handicapped?"

In the first example (Is a humanistically oriented classroom effective?), although the phrase humanistically oriented classroom may seem clear, many people may not be sure exactly what it means. It is not easy to describe its essential characteristics. What happens in such classrooms different from what happens in other classroom? Do teachers use certain kinds of strategies? Do they lecture? In what sort of activities do students participate? What do such classroom look like-how is the setting arranged, for example? What kinds of materials are used? Is there much variation to be found from classroom to classroom in the strategies employed by the teachers or in the sort of activities in which students engage? Do the kinds of materials available and/ or used vary?

The first term that needs clarification, in the second example (How do teachers feel about special classes for the educationally handicapped?), is "teachers." What age group does this involve? What level of experience? Are teachers both public and private schools included? Does the term refer to teachers who do not teach special classes as well as those who do? In addition, the phrase feel about is ambiguous. Does it mean opinions? Emotion reactions? Does it suggest actions? or What? The terms special classes and educationally handicapped also need to be clarified. Therefore, the writer of theses should take into account the clarity of words, phrases and sentences.

Mc. Millan (1992:35) explains that one of purposes of research problems is to communicate the purpose of study, a result that occurs only if the reader's understanding of the purpose is consistent with the researcher's. Also, a clear problem reflects the researcher's clear thinking. A clear problem includes terms that are not ambiguous. It is important to avoid technical language or jargon that may be well understood by others unless the report is intended to be read only by other professionals in a specified field.

Second, research problems should be researchable (Mc. Millan \& Scumacher, 1993:31; Ary et al. 2006:54). According to Moore (1983:53), a researchable problem is one we can study by collecting and analyzing data. There may be a lot of questions that can be asked in the areas of educational theories and practices. However, not all research problems are researchable (Wiersma, 1991:31) because they are concerned with value questions or philosophical ideas in a sense that a specific question has a correct answer (Mc.Millan,1992:31). Since a value question, has something to do with notions of right or wrong, proper and improper, according Fraenkel and Wallen (2006:26), it does not have any empirical (observable) referents. Let us look at the following example. "Should philosophy be included in high school curriculum?" There is no way to deal, empirically determine whether or not something "should" be done? What data do we collect? There is no way for us to proceed. 
To make this question researchable, the question can be, "Do people think philosophy should be included in the high school curriculum?" The data to such research problems can be collected to help researchers answer the question.

If we encounter non-researchable problems, we should make sure that we still can reformulate them to be researchable ones. Mc.Millan (1992:28) offers several examples of non-researchable research problems that have been changed to be researchable ones as can be seen in table 1.

\section{Table 1. Researchability of Research Problems}

\begin{tabular}{|l|l|}
\hline Non-Researchable & Researchable \\
\hline $\begin{array}{l}\text { Should we teach sex education in ele- } \\
\text { mentary school? }\end{array}$ & $\begin{array}{l}\text { What is the difference in knowledge } \\
\text { and attitudes of fifth graders taught ed- } \\
\text { ucation compared to fifth-graders who } \\
\text { are not taught sex education? }\end{array}$ \\
\hline $\begin{array}{l}\text { Do teachers need to have courses in test } \\
\text { construction? }\end{array}$ & $\begin{array}{l}\text { Will the classroom testing procedures } \\
\text { used by teachers who take a course in } \\
\text { test construction differ from those of } \\
\text { teachers who have not had the course? }\end{array}$ \\
\hline Should the school day be longer? & $\begin{array}{l}\text { What is the relationship between length } \\
\text { of the school day and SAT scores of } \\
\text { high school students? }\end{array}$ \\
\hline $\begin{array}{l}\text { Should learning-disabled students be } \\
\text { mainstream in English as well as in } \\
\text { physical education? }\end{array}$ & $\begin{array}{l}\text { What is the effect of mainstream fourth- } \\
\text { grade learning disabled students into } \\
\text { English classes on the self-concept, atti- } \\
\text { tudes and achievement of all students? }\end{array}$ \\
\hline
\end{tabular}

Third, research problems should indicate or specify the variables (Ary et.al, 2006:52; Mc. Millan, 1992:23). Variable must be observable or measurable in some way. When something cannot be measured, there is no tangible way to tell how it differ in quantitative or quality from one situation to another (Sowel and Casey, 1982:5). In a qualitative study, the total picture of a phenomenon is focused rather than breaking it down into variables (Ary et. al, 2006:31). The following are examples of research problems in which variables are shown. A research problem "Do the students taught with small group discussion have better reading achievement than taught with conventional method?" indicates two variables; teaching technique using small group discussion serves as independent variables and reading achievement serves as independent variables.
A research problem" Do vocabulary and structure correlate significantly with writing skill?" indicates three variables; vocabulary and structure act as predictors and writing acts criterion variables. A research problem "Do the more research article students read the better they write and argumentative essay?" indicates two variables, the number of time needed for reading research article and skill in writing argumentative essay.

Fourth, research problems should indicate research area (Borg \& Gall, 1983:87). Hatch adds that the more specific the area, the easier question should be to formulate clearly. Since the English Education Program of Islamic University of Malang University accepts the graduate of S-1 program majoring in Letter, English Education, and English Linguistics, it is assumed that the research areas will not go to far from their field of study, namely, the 
area of teaching and learning English, English literature, and linguistics.

Fifth, research problems should indicate research design (Ary, 1978, cited in Latief, 2004:34). Some of the most commonly used designs include qualitative, quantitative, corelational, causal, classroom action research (CAR), and research and development (R\&D). A research problem "How can drama technique be used to improve students' skill in speaking?" indicates that classroom action research is going to be used. A research problem "What kind of syllabus can be developed to meet the need of the Department of Informatics Management?" indicates research and development is going to be used. A research problem "Do the higher the students master the elements of paragraph, the better they can write an essay?" indicates co-relational is going to be used. A research problem "Do the students learning speaking skills taught by native speakers of English achieve better than those taught by non-native speakers?" indicates causal design is going to be used.

Sixth, the expected answers from research problems should be non-factual information on variables involved, it must explained the patterns of relationship among the variables, or system operating in the object of the study (Latief, 2004:44). More specifically, Hopkin (1981:112) stated research is directed toward developing a body of scientific principles about educational concerns. The research problems as in "What are the names of the teachers? What kinds of methods do the teachers use? How many teachers are in the school? How often do the teachers teach in a week?" are not research questions. They can be answered easily without necessarily gathering and analyzing data.

Seventh, research problems should be important or significant (Fraenkel and Wallen, 2006: 28; Mc. Millan, 1992:31). Wiersma (1991:31) equates the term "significant" or "important" with the "contribution" of research problems to the existing body of knowledge or education in a meaningful way. Research is worth doing as far as the results have theoretical and practical significances. In terms of theoretical contribution, some questions may arise: Are the results meaningfully related to what is already known? Do the results add new knowledge or change the way we understand the phenomena? Practical significance suggests that the results will have immediate use in day-to-day activities or decision. How will the results be used? All too often the answer to this question is not carefully thought out; as a result, a lot of data are gathered but not utilized (Mc. Millan,1992:31). For example, a research problem "How does general election reflect democracy?" is not a topic of interests for the students majoring English as a foreign language and has no theoretical and practical contribution.

Eighth, in addition to previous criteria, research problems should consider "the ethics" of research (Ary, 2002:52; Kumar, 1996:36). Ary et.al states further that unlike research in physical sciences, educational researchers are dealing with human subjects with feeling, sensitiveness, and rights who must be treated ethically. The term "ethics" has something to do with questions of right and wrong. When students think about "ethics", they may ask themselves if it is right or conduct. Fraenkel and Wallen (2006:54) suggest three very important issues that every researcher should address - the protection from harm, the ensuring of confidentially of research data, and the questions of deception of subjects.

Pertinent to relevant studies, there are some researchers who carried out studies dealing with several aspects of research. Wand (1965, cited in Persel, 1976:116) made a study on 125 articles. A sample of 125 articles was selected from 41 journals in 1962 on twenty-five characteristics. Two of these characteristics are relevant to the problem of a research paper's contribution to theory. Both revealed significant different in their rating assigned articles in education journals and in related professional journals. 
Ward, Hall and Schram (1975, cited in Borg \& Gall, 1983:194) found that the most frequent shortcomings were: specific designs (23 per cent), inadequate data on reliability and validity (22 per cent) and conclusions are not supported by the evidences (22 per cent). Persel (1976:303) studied articles published in 1967-68. A total 1100 article were used as a data source and qualitatively analyzed with respect to their substance and methodology. She found that the quality of educational research was quite low. When ratings of the three dimensions are averaged, 14 per cent of the papers were rated 'incompetence' compared only 5 per cent which were rated 'outstanding' on a five point scale. On the compressed three point scale, 39 per cent of the papers were rated below 'average' or 'incompetence' compared 30 per cent which were rated 'above average' or 'outstanding'.

Bakioglu and Kurnaz (2008:1) made research in Istanbul, Turkey. Their research was intended to reveal how academics perceive research quality and what they identify as the main problems that make it difficult to achieve quality in research. They proved that academics prefer most often methodological issues as the important quality criteria of research, followed by issues of theoretical background and originality. As the most importance of hindrances that make it difficult to achieve quality in research academics mentioned were lack of a long-established research culture, problems of research resources and the pressure caused by academic promotion criteria. Hall et. al (1988, cited in Bakioglu and Kurnaz, 2008:2) revealed that there were many serious methodological problems in scientific works. Hall et.al evaluated 54 published educational articles for their quality. The results indicated that 42 per cent of them were either unacceptable or needed major revision before getting published. The most commonly observed shortcomings were validity and reliability of data gathering procedures not established and research designs with weaknesses.

Srivasta (1984:122) studied the abstracts of 1,511 research investigations constitutes the basis of deductions about shortcomings and strengths of educational research in India. The following were the main shortcomings:

1) The dependence of some studies on library information and the use of secondary and tertiary sources of information.

2) Presentation of basic facts without attempts at interpretation as in research on the history of education.

3) Lack of familiarity of some investigators with research or contemporary work in India or abroad.

4) Frequent use of conventional tools of data collection which often put serious constrains on the scope of research, as in studies in the area of personality, learning and motivation.

5) Micro level studies without any macro treatment or vice versa.

6) Emphasis on psychometric rather than experimental approaches.

7) Broad generalization from studies with small sample.

8) Isolated ad hoc studies as in the area of programmed learning.

9) Lack of attempts to establish relationships with other fields.

Smith (in Gunderson, 1966: i) investigated 1,091 research proposals that came to Bureau of Research in USA. There were some inadequacies to be found, among others; 1 ) the non-delimitated problems, 2) the lack of theoretical framework from which to approach the problem, 3) lack of significance 4) the failure to examine thoroughly and critically previous research in the area (usually over-simplification of complex problems), 5) the provincialism in the review research (limited scope, geography, substance and method), 6) the failure to include review of related research in the proposal, 7) the failure to include objectives, hypotheses and questions or inclusion of broad or vague statements of 
objectives, 8) inadequacies in sampling, 9) failure to describe techniques and instrument to be used in the research, 10) incomplete description of the data, 11) the use of unscientific language or overuse of technical or pseudo technical language and 12) no control for the "hawthorne" effect.

Latief (2004:53-54) examined, evaluated, and classified research problems in the S-2 theses of the English Education Program at State University of Malang. He concluded that, in general, research problems had a good quality in terms of language used and in terms of contribution toward the development of language teaching and learning. He also found that there were 9 (nine) patterns of research problems in the S-2 theses of the English Education Program at State University of Malang. The patterns include: 1) research problems that require factual information for the answers, 2) research problems of which the answers are intended to measure the quality of tests, 3) research problems of which the answers should be obtained through an experimental research design, 4) research problems of which the answers should be gained through ex-post facto by comparing two of groups of students, 5) research problems of which the answers should be obtained by investigating the relationships among two or more variables, 6) research problems which require certain product such as instructional materials, syllabus, tests and so forth for the answers.7) research problems of which the answers require a developed instructional strategy that can be used to solve the immediate problems in classroom practice which is popular with Classroom Action Research (CAR), 8) research problems in the area of linguistics which are expected to contribute to language teaching and learning, 9) research problems in the area of literature of which the answers are results of analysis of literary works such as poetry, novel, song, drama, and so on which can contribute to language teaching and learning as well.
Winardi (1996:79) conducted a study of tests used in the research of students of the English program of Faculty of Teacher Training and Education of University of Tanjung Pura. He claimed that the Stratum -1 thesis writers in general were not satisfactorily constructing test items appropriate to cognitive domain. Some of these students were still poor at providing test items meeting cognitive domain they intended to measure. This indicated that they still lacked the ability in constructing such required items.

\section{METHOD}

Since the current study deals with the quality and the patterns of research problems, qualitative was as the approach and evaluation was the design. Although qualitative research was used, numbers or numerical data are needed to calculate distribution frequency of the topics being raised and types of the expected answers required by research problems. Commonly, in a pure quantitative design, the conclusion tends to rely on the most frequent data rather than the least frequent data. In this context, the frequency is used to see the pattern of data domination without ignoring the existence of least frequent data. All the theses were evaluated, described, and analyzed based on the following criteria; clarity, researchability, variables being involved, research areas, design, containing non-factual information, and significance.

\section{FINDINGS AND DISCUSSION}

The quality of research problems can be seen in terms of clarity, researchability, variables being involved, research areas, designs, non-factual data or information, and significance. Each is discussed in the following ways.

\section{Clarity}

Clarity has to with words, phrase or sentences used in constructing research problems. The majority of the research problems studied shows clarity. However, there are only a very few errors which still occur. Let us take a look 
at research problems by Luqman (2005:4) and Dimyati (2008:8). (1) What kinds of metaphors in the story of Dewaruci? (2) What kinds of symbols use in metaphor? (3) What meaning stated by the symbol? (Luqman, 2005:4).

The first statement of the research problem is not completed yet because to be "are" is unavailable to link between the question "What kinds of metaphors" and "in the story of Dewaruci." To fill in the missing link, to be "are" should be used as in the sentence, "What kinds of metaphors are in the story of Dewaruci?" Alternatively, the sentence should be changed into the passive form, "What kinds of metaphors are in the story of Dewaruci?. The second statement for research problems does not make any sense because the verb "use" should be followed by an object, while in that sense, the verb "use" is followed by an adverb of place. In order to produce the correct form of the sentence, "What kinds of symbols use in metaphor?" should be revised to be "What kinds of symbols are used in metaphor?". The sentence can be grammatically acceptable if to be "are" is not omitted. Therefore, the recommendation for the research problem would be, "What meanings are stated in the story of Dewaruci?"

Another error occurs in the research problems by Dimyati (2008:8) namely (1) What is the qualification of the teacher? (2) How are the teaching preparation of English teacher? (3) How does the teacher apply standard curriculum? 4) How does the teaching learning process take place in the classroom? (5) The students' opinion toward teaching-learning process conducted by the teacher in classroom (6) What kind of evaluation does the teacher apply? (Dimyati: 2008:8). The error can be found out in the second sentence in which to be "is" is used instead of to be "are." The recommendation revision for that sentence would be, "How is the teaching preparation of English teacher?" or "How are the teaching preparations of English teacher?"

The fifth research problem is a long phrase, not a question. Therefore, it should be changed into the questions, "How is the students' opinion toward teaching-learning process conducted by the teacher in classroom?" The errors should not occur in the research problems because graduate students of English are those who are professionally capable in their field. Leedy (1980:52) suggests that the problems should be stated in a complete grammatical sentence. In that way, the readers will catch the ideas, intentions or thought reflected in the research problems.

\section{Researchability}

Researchability is closely related to the expected data to answer the questions. As far as the value questions (including theological or philosophical questions) are not raised, the answers can be easily obtained by collecting and analyzing data. All graduate theses of the English Education Program at Islamic University of Malang from 2003-2008 did not contain value questions such as "should," "ought," "must" are not found in research problems. Therefore, All graduate theses of the English education program at Islamic University of Malang from 2003-2008 indicate researchability.

\section{Variables being involved}

Variables are always involved in both quantitative and qualitative research. In quantitative research, researchers commonly study variables and see the relationships existing among the variables and the nature of variables. In qualitative variables, researchers tend to focus on the holistic pictures and depth understanding of a phenomenon rather than break into variables. Yuliatin (2008:2) uses three variables; vocabulary, structure and writing. Do vocabulary and structure mastery correlate significantly with writing ability at the first grade of Madrasah Aliyah Negeri I Banyuwangi in 2007/2008 Academic Year? (Yuliatin,2008:2).Vocabulary and structure are variables of predictors and writing ability is a criterion variable.

Salman(2007:7) used twovariables; learnedcentre instruction and reading achievement. Do the students of MAN Banyuwangi taught 
with learned-centre instruction have better reading achievement than those taught with teachercentre instruction. He attempted to compare learned center instruction and teacher center instruction in teaching reading. Based on the analysis of the research problems, it can be said that most graduates theses of the English Education Program at Islamic University of Malang from 2003-2008 indicate variables being involved clearly.

\section{Research Areas}

Research area can be found out from the topics as reflected in the research problems. According to Latief (2009:9), research problems should be related to the topics of English teaching and learning, linguistics and literature. To what extent the graduates' theses indicates research areas, table 2 presents the results. The data clearly shows that the topics in language teaching and learning are in the top rank of the students' choice $(86.2 \%)$, the topics in literature are in the middle rank of the students' choice (11.1\%), and the topics in linguistics are in the bottom rank (3.7\%).

Table 2. Distribution of Research Areas Indicated in the S-2 Theses of the English Education Program at Islamic University of Malang from 2003-2008 contexts. Following are examples of research problems in language teaching and learning by (Suyoto, 2006:6) and Gunadi (2004:13). Is there any positive correlation between achievement in Mathematic and Achievement in English of the Fifth Year Students at SDN 7 Kedunggebang, Tegaldlimo Sub-District Banyuwangi Regency in 2006/2007 Academic Year? (Suyoto, 2006:6). Suyoto attempted to determine the degree of the relationship exists between the principles of learning mathematics and learning English. What kind of English syllabus can be developed to meet the need of the Department of Hotel Management, Diploma III in Tourism, Merdeka University of Malang?(Gunadi, 2004:13). Gunadi develop English syllabus to the students who major in tourism, Merdeka University of Malang.

\section{Research Problems in the Area of Linguis- tics}

Linguistics is a study of the principles, rules and systems of the language. There are sub-disciplines such as sociolinguistics, psycholinguistics, semantics, discourse analysis and so forth. Following are examples of research problems in Linguistics by Mujadaya (2004:4) Masduki (2006:6) and Yatno (2006:4). What types, functions and speech acts do sentences

\begin{tabular}{lllll}
\hline Years & $\begin{array}{c}\text { Language Teaching and } \\
\text { Learning }\end{array}$ & Linguistics & Literature & Total \\
\hline 2003 & 2 & - & - & 2 \\
2004 & 10 & 2 & 2 & 14 \\
2005 & 13 & - & 4 & 17 \\
2006 & 17 & 2 & 4 & 23 \\
2007 & 25 & - & 3 & 28 \\
2008 & 31 & - & 3 & 41 \\
Total & $115(85.2 \%)$ & $4(3.7 \%)$ & $16(11 . \%)$ & $135(100 \%)$
\end{tabular}

\section{Research Problems in the Area of Language Teaching and learning}

The research problems in language teaching and learning are derived from the actual problems in the language teaching and learning of motorized vehicle advertisements published in by Jawa Pos have? (1) what types of sentences are more frequently used in the headlines of Jawa Pos? (2) what language functions are more frequently used in the headlines of Jawa Pos? (3) what speech 
acts do the headlines of car and motorized vehicle advertisement in Jawa Pos have? (Mujadaya, 2004:4). Mujadaya emphasized on the types, the functions and speech acts represented by sentences in advertisements as published by Jawa Pos.

How are the argumentative devices reflected in Abdurrahman Wahid's English articles that are issued in www.gusdur.net? (1) which words, phrases and sentences of $A$. Wahid inclusive of the argumentative devices?(2) How does Abdurrahman Wahid convey his arguments through argumentative devices in Abdurrahman Wahid's English articles (3) what is the frequency of occurrence of argumentative devices in Abdurrahman Wahid's English articles (Masduki, 2006:5). Masduki focused on one variant of discourse analysis, that is, by analyzing the argumentative devices used in Abdurrahman Wahid's English articles that are issued in www.gusdur.net.

How are the speeches delivered by President George Walker Bush? (1) How does President George Walker Bush organize his speech? (2) What (discourse) pattern he utilizes in his speech? (Yatno, 2006:4). Yatno highlighted rhetoric as used by George Walker Bush by analyzing the pattern of Bush's speeches.

\section{Research Problems in the Area of Literature}

Literature is a part of language. To understand literature means to understand how language works or lives. Following are examples of research problems in literature by Fauzi (2004:9), Ma'rifah (2006:9), and Rachmah (2006:6): (1)Which ethical value does include goodness, humanism and collective tradition? (2) Which didactive value does include intellectual and nationalism? (Fauzi, 2004:9). Fauzi raised the questions dealing with ethical values which can be good models for the students.

(1) How are the characters' personality on psychology of analytical theories in crime and punishment? (2) How are the characters' personality seen from the philosophy of existentialism in crime and punishment? (Ma'rifah, 2006:9). Ma'rifah highlighted the characters' personalities in a short story. What are the elements of poetry used in selected poems of Satrowardoyo's foreign shores? (Rachmah, 2006:5). Rachmah analysed the element of poetry in selected poems of Sastrowardoyo's foreign shores.

\section{DESIGN}

There are different sort of research designs can be seen from the current research problems. Research designs include quantitative or qualitative, causal, co-relational, classroom action research, and development research. Based on the different sort of research designs reflected in research problems, it can be concluded that all research problems in the S-2 theses of the English program at Islamic University of Malang show designs.

\section{Qualitative Design}

Following is an example of research problems using qualitative design as shown by Sholehah (2006:6):

How are rhetorical features as manifested in the expository essay by EFL students of S-1 English program at Kanuruhan University of Malang? (1) how are the rhetorical structures of the expository essay made by EFL of S-1 English program of Kanjuruhan University of Malang? (2) how is the development of linearity or non-linearity rhetorical patterns used in the expository essay made by EFL of S-1 English program of Kanjuruhan University of Malang? (3) how are the development of paragraphs used in the expository essay made by EFL of S-1 English program of Kanjuruhan University of Malang (4) how are the topic sentence and supporting detailed in paragragh writing of the expository essay made by EFL of S-1 English program of Kanjuruhan University of Malang? (Sholehah,2006:6). Sholehah attempted to compare how the rhetoric features of English and Indonesian essay made by EFL undergraduate indicate similarities and differences. The rhetorical features include general patterns of thought (linear or non-linear), development of ideas, and coherency. 


\section{Evaluative Design}

Azizah (2006:5) made an evaluation on a try out test for national examination of junior high school. Following is her research problems: Does the English try out test for National Examination of Junior High School constructed by the team of English teachers in Pamekasan in the 2005/ 2006 academic year have the criteria of a good test? (1)Does the English try out test for National Examination of Junior High School constructed by the team of English teachers in Pamekasan in the 2005/ 2006 academic year have the criteria of a good content? (2) Does the English try out test for National Examination of Junior High School constructed by the team of English teachers in Pamekasan in the 2005/ 2006 academic year have the criteria of a high reliability ?(3). Does the English try out test for National Examination of Junior High School constructed by the team of English teachers in Pamekasan in the 2005/ 2006 academic year have the criteria of a good practicality?(4) Does the English try out test for National Examination of Junior High School constructed by the team of English teachers in Pamekasan in the 2005/2006 academic year have the criteria of a good difficulty level? (5) Does the English try out test for National Examination of Junior High School constructed by the team of English teachers in Pamekasan in the 2005/ 2006 academic year have the criteria of a good discrimination power? (Azizah, 2006:5). The quality of test can be measured in terms of content, practicality, and difficulty level and discrimination power.

\section{Experimental Design}

The following is an example of research problems in experimental design by Salman (2007:7): Do the students of MAN Banyuwangi taught with learned-centre instruction have better reading achievement than those taught with teacher-centre instruction (Salman, 2007:7). Salman attempted to measure the effectiveness of learned center instruction and teacher center in teaching reading.

\section{Ex-post Facto Design}

Ex-post facto research measures the difference in the dependent variable that already exists without making any treatment to variables. The following are research problems by Kusrini and Syahroni (2007). 1) Is there any difference in the English achievement between the Students of SLTPN-2 Dolopo Madiun and those of MTs Dolopo-2 Madiun? 2) Is there any difference in the teaching-learning process between the Students of SLTPN-2 Dolopo Madiun and those of MTs-2 Dolopo Madiun? Kusrini,(2003:3)

Do female students have significantly better motivation than males in learning English? Do female students have significantly better achievement than males in learning English? Is there a significant correlation between students English learning motivation and their achievement? (1) Is there a significant correlation between females' English learning and their achievement?(2) Is there a significant correlation between males' English learning motivation and their achievement?(3) Which indicator of motivation has strongest significant correlation to the students' English achievement? (Syahroni, 2007:6)

\section{Co-relational Design}

In co-relational research, the correlation among variables is measured. Following is an example of co-relational research by (Fahrorazi, 2008:4). Do the grammar and vocabulary mastery have correlation with reading comprehension of the students of SMAN-2 Pamekasan? (Fahrorazi, 2008:4)

\section{Classroom Action Research Design}

In this kind of design, a research problem requires a certain product that is considered to be effective in solving the actual classroom problems. Following are examples of research problems in Classroom Action Research by Sari (2004:6) and Hartini (2007:4). How can the students' writing skills be improved by using peer-editing activities in classssroom? (Sari, 2004:6). Sari wanted to develop writing skill using peer-editing strategies.

How do supplementary materials improve 
the listening ability of the second year students of English education of Jember Muhammadiyah University? (Wahono, 2006). Wahono wanted to improve listening ability using supplementary materials

How does small group work improve the speaking performance at the second year students at Bojonegoro?(Hartini, 2007:4). Hartini wanted to improve speaking ability using small group work.

\section{Research and Development Design}

Research and Development (R\&D) is a kind of design in which the expected answers are in the form of developed products such as syllabus, materials and media. Following are examples of research problems by Gunadi (2004:13), Andriani (2005:9) and Must'ain (2005:5) which require a product in the form of a syllabus, materials, instructional media, and so forth. What kind of English syllabus can be developed to meet the need of the Department of Hotel Management, Diploma III in Tourism, Merdeka University Malang? (Gunadi, 2004:13). Gunadi attempted to develop syllabus for the students who major in tourism.

What materials can be developed to suit the needs and objectives of English lessons at D-3 Tourism Merdeka University Malang? (Andriani, 2005:9). Andriani developed materials to meet the need and objective of English lesson at Merdeka University Malang.

\section{Non- factual Information}

Non-factual information means that the research problems do not merely require the facts or the data for the answers. There should be process of analyzing undertaken and the inference should be made on the results of analyzing the data. There are several types of research whose answers non-factual information, among others, quantitative or qualitative, causal, co-relational, classroom action research, and development research. $91(67 \%)$ of the theses need non-factual information while $44(37 \%)$ of the theses require factual information.
The majority of the research problems as written in the S-2 theses of the English Education Program at Islamic University of Malang from 2003-2008 fulfill the criteria of good research problem in terms of contain non-factual information. However, there are a few theses which contain factual information for the answers. Following are the examples of research problems by Susatyo (2004:6), Riyanto (2008:5) and Widiantono (2008:4). (1) How is the readiness of English teachers at SLTP PGRI -3 Tuban and SLTP Negeri-1 Tambakbuyo to Implement Contextual Teaching and Learning? (2) How does the teacher implement Contextual Teaching and Learning at SLTP PGRI-3 Tuban? (3) How does the teacher implement Contextual Teaching and Learning at SLTP Negeri-1 Tambakboyo? (4) What is the teacher's beliefs supporting the instructional practices which take place in the class with reference to the use of teaching materials at SLTP PGRI 3 Tuban?(5)What is the teacher's beliefs supporting the instructional practices which take place in the class with reference to the use of teaching materials at SLTP Negeri-1 Tambakboyo? (6) What is the teacher's beliefs supporting the instructional practices which take place in the class with reference to the use of methods and techniques of teaching at SLTP Negeri-1 Tambakboyo? (7) What is the teacher's beliefs supporting the instructional practices which take place in the class with reference to language classroom at SLTP-3 Tuban and SLTP Negeri-1 Tambakboyo?(9). What is the teacher's beliefs supporting the instructional practices which take place in the class with reference to students at SLTP-3 Tuban and SLTP Negeri-1 Tambakboyo? (Susatyo, 2004:6). The answers to research problem 1 and research problem 2 can be obtained by describing the readiness of the English teachers, the activities of teachers in applying CTL, and the teachers' belief without analyzing the data acquired

How is the teaching preparation made by the teacher of MAN Pamekasan? How is the activity of KTSP teaching-learning process? (1)How are the steps made for teaching-learning activities? 
(3) How are the materials presented in teaching?

(4)What media are used in teaching? (5)What methods are applied in teaching? How is the assessment carried out? (Riyanto, 2008:5). The answers to research problem 1 , can be obtained by describing the activities of the teachers in preparing themselves before teaching, the materials being used, the media, the method and the activities of the teachers in assessing the students.

How is the teaching of writing skill conducted at SMP Negeri 1 Genteng Banyuwangi as integrated with other skills in the classroom?(1).How do the English teachers plan the teaching of writing skill? (2).How do the English teachers teach writing skill as integrated with other skills? (3). How is the classroom assessment conducted in writing class at SMP Negeri-1 Genteng Banyuwangi? (Widiantono, 2008:4). The research problems as proposed by Widiantono, require factual information about the teachers' plans, the activities of the teachers in teaching, and the activities in assessment.

Although there are still a few students us need factual information in their theses, the majority of the graduate theses of the English education program at Islamic University of Malang from 2003-2008 contain non-factual information.

\section{Significance}

If we refer to table 2, the topics in language teaching and learning dominate the research areas $(86.2 \%)$. It indicates that the expected to research problems help teachers understand the relationships among the phenomena (variables), the innovative methods, develop products in the forms of syllabus, or solve the problems in actual practice. On the basis of the significance, it can be concluded that the majority of the graduate theses of the English Education Program at Islamic University of Malang from 2003-2008 have theoretical and practical contributions to the teaching of English as a foreign language.

\section{The Pattern of the Research Problems}

After identifying, classifying, evaluating, and analyzing the general characteristics research problems as written in the S-2 theses of the English education program at Islamic University of Malang from 2003-2008, it was found out that there were 9 (nine) patterns of research problems: 1) research problems that require factual information for the answers, 2) research problems of which the answers are intended to measure the quality of tests, 3) research problems of which the answers should be obtained through an experimental research design, 4) research problems of which the answers should be gained through ex-post facto by comparing two of groups of students, 5) research problems of which the answers should be obtained by investigating the relationships among two or more variables 6) research problems which require certain product such as instructional materials, syllabus, tests and so forth for the answers, 7) research problems of which the answers require a developed instructional strategy that can be used to solve the immediate problems in classroom practice, namely classroom action research (CAR), 8) research problems in the area of linguistics are expected to contribute to language teaching and learning, 9) research problems in the area of literature of which the answers are results of analysis of literary works such as poetry, novel, song, drama and so on can contribute to language teaching and learning.

\section{CONCLUSIONS}

In an attempt to answer the first research problem of the study, the quality of the S-2 theses of the English education program at Islamic University of Malang from 2003 to 2008 can be judged from 7 (seven) criteria, namely, clarity, researchability, variables being involved, research areas, research designs, containing non-factual information, and significance or contribution. 
The investigation to the general characteristics research problems as written in the S-2 theses of the English education program at Islamic University of Malang from 2003-2008, showed that there were 10 (ten) patterns of research problems, which revealed:1) research problems require factual information for the answers, 2) research problems that require qualitative analysis for the answers, 3) research problems whose answers are intended to measure the quality of tests, 4) research problems of which the answers should be obtained through an experimental research design, 5) research problems whose answers should be gained through ex-post facto by comparing two of groups of students, 6) research problems of which the answers should be obtained by investigating the relationships among two or more variables, 7) research problems whose answers require certain product such as instructional materials, syllabus, tests and so forth for the answers, 8) research problems of which the answers require a developed instructional strategy that can be used to solve the immediate problems in classroom practice, 9) research problems in the area of literature of which the answers are results of analysis of literary works such as poetry, novel, song, drama and so on can contribute to language teaching and learning, and 10) research problems in the area of linguistics whose answers are expected to contribute to language teaching and learning as well.

\section{REFERENCES}

Andriani, Christina. (2005). Developing a Communicative Based Textbook for D-3 Tourism Merdeka University Malang. Unpublished Thesis. Malang: Islamic University of Malang.

Ary, Donald, Jacobs, Luci Cheser, and Razavieh, Asghar. (2006). Introduction to Research in Education. Belmont, CA: Wadsworth Thomson Learning.
Azizah. (2006). An Analysis of English Try Out Test for National Examination of Junior High School in Pamekasan. Unpublished Thesis. Malang: Islamic University of Malang.

Borg, Walter R. and Gall, Meredith Damien. (1983). Educational Research. An Introduction. New York: Longman

Dimyati. (2008). The Teaching of English at Madrasah Tsanawiyah Negeri Banyuwangi-1. Unpublished Thesis. Malang: Islamic University of Malang.

Fauzi, Ali. (2004). Values of Life in William Shakespear's King Lear. Unpublished Thesis. Malang: Islamic University of Malang.

Fraenkel, Jack R. and Wallen, Norman. (2006). How to Design and Evaluate Research in Education. San Francisco: Mc. GrawHall-Hill Inc.

Gay, L R. (1987). Educational Research. Competencies for Analysis and Application. Toronto: Merril Publishing Company.

Gunderson, Doris V. (1966). Flaws in Research Design. Talk Given at Annual Meeting of National Reading Conference. December 2 2n, 1966.

Kerlinger, Fred N. (1981). Foundations of Behavioral Research. Tokyo: Holt Gaunder Japan ltd.

Kumar, Ranjit. (1996). Research Methodology. Australia: Adisson Wesley Longman.

Kusrini, Eny. (2003). A Comparative Study on the English Achievement of the Students of SLTPN-2 Dolopo Madiun and MTs Dolopo Madiun. Unpublished Thesis. Malang: Islamic University of Malang.

Latief, Adnan. (2004). Rumusan Masalah Dalam Tesis Program Studi Pendidikan Bahasa Inggris Pascasarjana Universitas Negeri Malang. 14(1): 34 Jurnal Ilmu Pendidikan

Latief, Adnan. (2009). Research Problems and Objectives in Language Learning. 
(http//sastra um. ac;id/w. pcomment_post:php retrieved on February, $\left.2^{\text {nd }}, 2010\right)$

Leedy, Paul D. (1980). Practical Research: Planning and Design. New York: Macmillan Publishing Comp, Inc.

Luqman. (2005). The Metaphors Used in Serat Pedhalangan Lampahan Dewaruci, by Soedarko, S.Ka. Unpublished Thesis. Malang: Islamic University of Malang.

Ma'rifah, Ulfatul. (2006). An Analysis of Characters' Personality through Psychology of Analytic and Philosophy of Existentialism in Crime and Punishment. Unpublished Thesis. Malang: Islamic University of Malang.

Masduki, Harits. (2006). Argumentative Devices in K.H Abdurrahman Wahid's English Articles Issued in www.gusdur.net. Unpublished Thesis. Malang: Islamic University of Malang.

Mc. Millan, James H. (1992). Educational Research. Fundamentals for the Consumers. New York: Harper Collins Publisher.

Mc. Millan, James H. and Scumacher, Sally. (1993). Research in Education. New York: Harper Collins Publisher.

Mujadaya. (2004). Discourse Analysis of Motorized Vehicle Advertisement Published by Jawa Pos. Unpublished Thesis. Malang: Islamic University of Malang.

Moore, Gary W. (1983). Developing and Evaluating Educational Research. Boston: Little, Brown and Company.

Gunadi, Kun Aniroh M. (2004). Developing an English Syllabus for Diploma III in Tourism Merdeka University Malang. Unpublished Thesis. Malang: Islamic University of Malang.

Persel, Caroline Hodge. (1976). The Quality of Research on Education. An Empirical Study of Research and their Work. New York: Bureau of Applied Social Research, Columbia University.
Rachmah. (2006). Analysis of Elements of Poetry in Selected Poems of Subagio Sastrowardoyo's on Foreign Shores. Unpublished Thesis. Malang: Islamic University of Malang.

Riyanto, Slamet. (2008). A Study on English Teaching Based on School Based Curriculum to Grade $X$ Students at MAN Pamekasan. Unpublished Thesis. Malang: Islamic University of Malang.

Salman. (2007). The Effectiveness of LearnerCentered Instruction to Increase Reading Skills of the Third Year Students at MAN Banyuwangi. Unpublished Thesis. Malang: Islamic University of Malang.

Sari, Diah Ratna. (2004). Improving Students' Writing Skills Using Peer-Editing Strategy in the Writing Process at Fourth Semester of Muhammadiyah University of Malang. Unpublished Thesis. Malang: Islamic University of Malang.

Sholehah, Imrotatus. (2006). Rhetoric as Manifested in the Expository Essay by EFL Students of Kanjuruhan University of Malang. Unpublished Thesis. Malang: Islamic University of Malang.

Sowel, Evelyn J. and Casey, Rita J. (1982). Analysing Educational Research. California: A Division of Wadsworth.

Srivasta, H.S. (1984). World of Yearbook of Education. Research, Policy and Practice. New York: Kogan Page.

Susatyo, Budi. (2004). The Readiness of English Teachers at SLTP PGRI -3 Tuban and SLTP Negeri-1 Tambakbuyo to Implement Contextual Teaching and Learning (A Case Study at SLTP PGRI-3 Tuban and SLTP Negeri-1 Tambakboyo). Unpublished Thesis. Malang : Islamic University of Malang.

Suyoto. (2006). A Correlation between Achievement in Mathematics and Achievement in English of the Fifth Year Students at SDN 7 Kedunggebang, Tegaldimo Su-Distric Banyuwangi Rengency in 
2006/2007 Academic Year. Unpublished Thesis. Malang: Islamic University of Malang.

Tuckman, Bruce W. (1999). Conducting Educational Research. New York: Harcourt Brace College Publisher.

Wahono, Suparwoto Sapto. (2006). Improving Listening Ability through Recorded Supplementary Materials. Unpublished Thesis. Malang: Islamic University of Malang.

Widiantono, Bowo Aris. (2008). The Teaching of Writing Skill at SMPN-1 Genteng Banyuwangi. Unpublished Thesis. Malang: Islamic University of Malang.

Wiersma, Willian. (1991). Research Methods in
Education. An Introduction. Boston: A division of Simon and Schuster, Inc.

Yatno. (2006). The Organizations of and Patterns of the Speeches of George Walker Bush. Unpublished Thesis. Malang: Islamic University of Malang.

Yuliatin. (2008). The Predictability of Writing Ability from Vocabulary and Structure Mastery at the First Year Students of MAN I Banyuwangi. Unpublished Thesis. Malang: Islamic University of Malang.

Winardi, Aloysius. (1996). Tests Used in the Research of the Students of the English Program of the Faculty of Teacher Training and Education of the University of Untan Pontianak. Unpublished Thesis. Malang: State University of Malang. 
